Supporting Information

\title{
Sources of blood lead exposure in rural Bangladesh
}

4

$8{ }^{1}$ Emmett Interdisciplinary Program in Environment and Resources, Stanford University,

9 Stanford, California, U.S.A.

$10 \quad{ }^{2}$ Earth System Science, Stanford University, Stanford, California, U.S.A.

11 3nfectious Diseases Division, International Centre for Diarrhoeal Disease Research, Bangladesh,

12 Dhaka, Bangladesh

$13{ }^{4}$ Environmental Interventions Unit, International Centre for Diarrhoeal Disease Research,

14 Bangladesh, Dhaka, Bangladesh

$15{ }^{5}$ Stanford Center for Innovation in Global Health, Stanford University, Stanford, California, 16 U.S.A.

17

22 Length summary:

Pages: 21

24

Figures: 8

25

Tables: 7 
29 TABLE OF CONTENTS

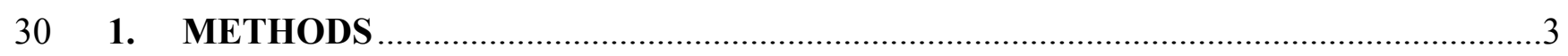

$31 \quad 1.1 \quad$ Environmental sampling and consumption behavior interviews ....................................

$32 \quad 1.2 \quad$ Testing the feasibility of $\mathrm{Pb}$ transfer from cans to food.................................................

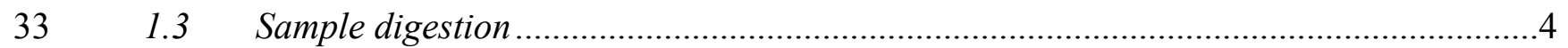

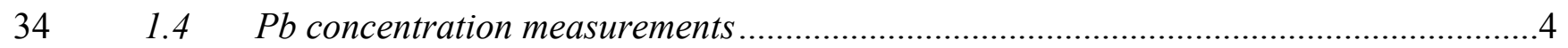

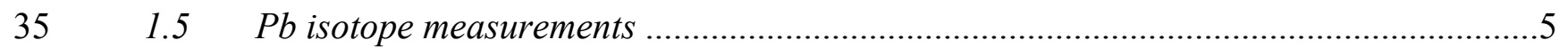

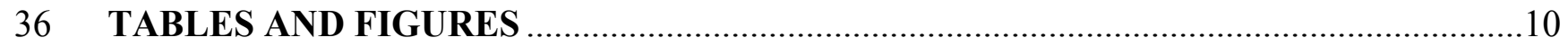

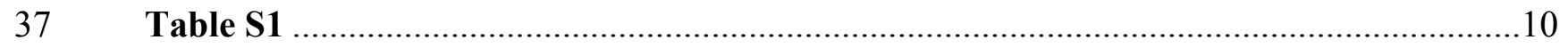

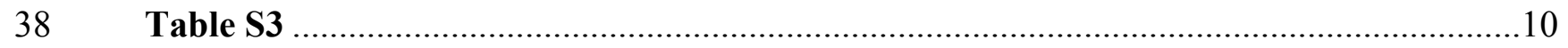

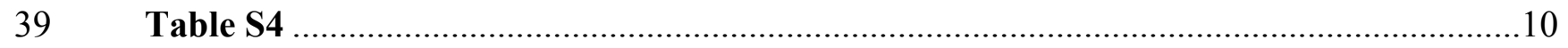

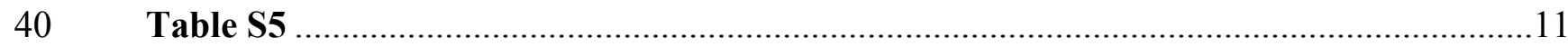

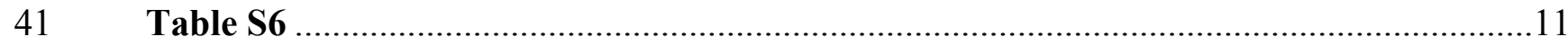

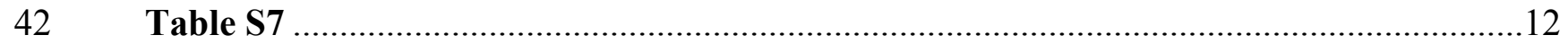

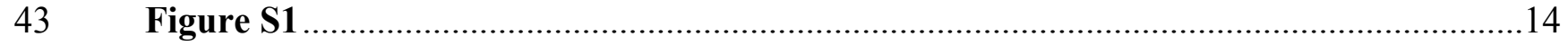

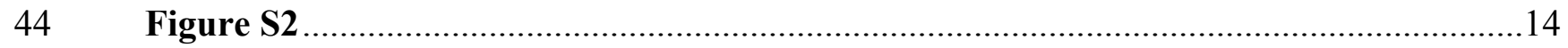

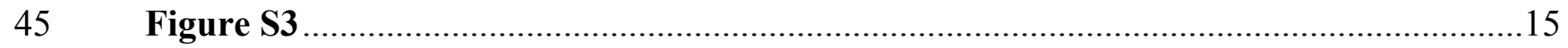

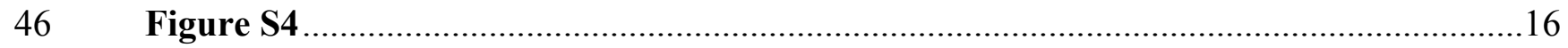

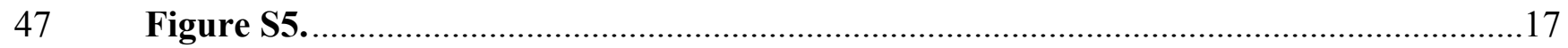

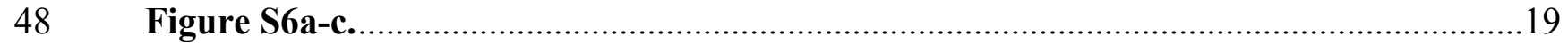

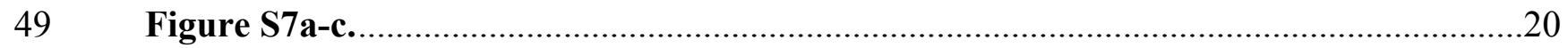

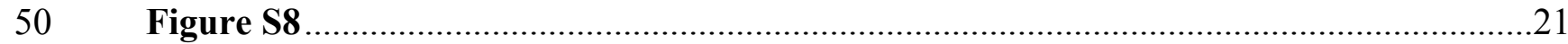

51

52

53

54 


\section{METHODS}

\subsection{Environmental sampling and consumption behavior interviews}

Research assistants used criterion-based and snowball sampling to identify individuals with whom to conduct semi-structured interviews to learn about each source or exposure

59 pathway and to collect samples. Criteria for selecting interviewees included a) individuals' blood

$60 \mathrm{~Pb}$ level (BLL) (if a study participant) and $\mathrm{b}$ ) level of knowledge or experience about the sources

61 of $\mathrm{Pb}$. As needed, additional respondents were identified via a snowball sampling approach,

62 whereby initial respondents were asked who else might be knowledgeable. Additional

63 interviewees were selected by observing processing, selling, and buying behaviors of $\mathrm{Pb}$ -

64 contaminated products.

65 To collect samples of food from Pb-soldered cans, field research assistants identified 20

66 individuals who consumed food from $\mathrm{Pb}$-soldered cans in the study region. In order to find 20

67 individuals with $\mathrm{Pb}$-soldered cans, research assistants screened 100 residents. Twenty more

68 individuals were selected from the region based on similar socioeconomic status who consumed

69 food from $\mathrm{Pb}$-free containers.

70 To collect geophagous samples, we visited 10 study participants with high BLLs (9-29

$71 \mu \mathrm{g} / \mathrm{dL} \mathrm{Pb}$ ) and 10 with $<2 \mu \mathrm{g} / \mathrm{dL} \mathrm{Pb}$. We conducted interviews to understand ingestion practices

72 of clay and ash and to obtain samples. We conducted all interviews in Bengali, audio-recorded

73 interviews, and later transcribed and translated them to English.

1.2 Testing the feasibility of $\mathrm{Pb}$ transfer from cans to food

Since all food stored in the cans was dried, the hypothesized mechanism of $\mathrm{Pb}$

76 contamination was from physical abrasion or rusting of the iron can adjacent to the $\mathrm{Pb}$ solder that

77 could result in the release of solid particles of $\mathrm{Pb}$ entering the food. To test the mechanism and 
78 feasibility of $\mathrm{Pb}$ transfer from cans into food, we conducted an experiment in duplicate with five

$79 \mathrm{~Pb}$-soldered cans and one control (non- $\mathrm{Pb}$-soldered) can (Figure $\mathrm{S} 2$ ). The $\mathrm{Pb}$ concentration of

80 puffed rice was measured before and after 20 minutes of being shaken in these cans. Following

81 the can experiment to elucidate the $\mathrm{Pb}$ transfer mechanism, puffed rice $\mathrm{Pb}$ concentrations ranged

82 from 4-120 $\mu \mathrm{g} / \mathrm{g} \mathrm{Pb}$ compared to less than $1 \mu \mathrm{g} / \mathrm{g} \mathrm{Pb}$ in the control can and less than the limit of

83 detection $(0.01 \mu \mathrm{g} / \mathrm{g})$ prior to the experiment (Figure S4).

\subsection{Sample digestion}

85 Turmeric samples and food from $\mathrm{Pb}$-soldered cans were digested in concentrated nitric

86 acid $\left(\mathrm{HNO}_{3}\right)$. Solder from food storage canisters was digested in $5 \mathrm{~N}$ hydrochloric acid $(\mathrm{HCl})$.

87 Pigments were digested with 7.5 $\mathrm{N} \mathrm{HNO}_{3}$. Geophagous samples (ash and clay) were digested

88 using $\mathrm{HNO}_{3}$ and used for $\mathrm{Pb}$ concentration determination. For isotopic analysis, geophagous

89 samples were prepared in a clean lab facility (details below in $\mathrm{Pb}$ isotope section) and digested

90 using microwave digestion (CEM Mars Xpress) in ultra-pure concentrated $\mathrm{HNO}_{3}$ and

91 hydrofluoric acid (HF). Blood samples for isotopic analysis were digested with ultra-pure

92 concentrated hydrogen peroxide $\left(\mathrm{H}_{2} \mathrm{O}_{2}\right)$ and $\mathrm{HNO}_{3}$ in a clean lab. Blood was heated on a hotplate

93 at $90^{\circ} \mathrm{C}$ for 12 hours. Additional $\mathrm{H}_{2} \mathrm{O}_{2}$ was added until solution was transparent and no particles

94 remained in solution. Table S2 provides clarification on the purity of reagents used for each type 95 of digestion.

$96 \quad 1.4 \mathrm{~Pb}$ concentration measurements

97 Blood $\mathrm{Pb}$ concentrations were measured at the Nutritional Biochemistry Laboratory at the

98 International Center for Diarrheal Disease Research, Bangladesh (icddr,b). Samples were

99 analyzed via atomic absorption spectroscopy following the US Centers for Disease Control and

100 Prevention procedure for $\mathrm{Pb}$ in blood. ${ }^{1}$ 
For all other samples except pigment and geophagous samples, $\mathrm{Pb}$ concentrations of acid-

102 digested material were analyzed by quadrupole inductively coupled plasma mass spectrometry

103 (ICP-MS) on ThermoFisher iCap X-series in Stanford's Environmental Measurements Facility.

104 Samples were aspirated in $2 \% \mathrm{HNO}_{3}$ in parallel with an internal standard solution to correct for

105 instrumental drift. Samples were standardized to multi-element reference solutions. Sample Pb

106 concentrations were reproducible to within $6 \%$ based on duplicate measurements. A sub-set of

$10720 \%$ of samples were analyzed for $\mathrm{Pb}$ concentration in duplicate. Pigment and geophagous

108 sample $\mathrm{Pb}$ concentrations were measured via X-Ray Fluorescence (XRF).

\subsection{Pb isotope measurements}

110 A limited amount of blood was available for analysis in this study. With less than $25 \mathrm{ng}$

111 total $\mathrm{Pb}$, great care was taken to avoid external contamination of blood samples from naturally

112 occurring $\mathrm{Pb}$ in the environment. Blood and geophagous samples were handled and prepared

113 only in the Stanford ICPMS/TIMS Clean lab facility. The facility includes a Class $<1000$ clean

114 lab with dedicated $\mathrm{Pb}$ workstations maintained at Class 10 conditions. All reagents were

115 ultrapure reagents $\left(\mathrm{Optima}^{\circledR}, \mathrm{BDH}^{\circledR}\right.$ or Suprapur $\left.{ }^{\circledR}\right)$ with less than $1 \mathrm{ppt}(1 \mathrm{ng} / \mathrm{L})$ of elements of

116 interest - including $\mathrm{Pb}$. All labware was acid-washed Savillex ${ }^{\circledR}$ PFA vials. All other samples -

117 food, solder, pigment, and turmeric - were digested in a standard wet laboratory and solution

118 aliquots were transferred to clean lab beakers for chemical separation in the clean lab. Blanks

119 from the wet lab sample processing procedure were evaluated and determined to not contribute a

120 significant quantity of $\mathrm{Pb}$ to the samples that were processed in the wet lab.

121 Analysis of $\mathrm{Pb}$ isotopes by multicollector ICP-MS (MC-ICP-MS) provides the ability to

122 achieve higher precision than analysis of $\mathrm{Pb}$ isotope by single collector quadrupole ICPMS.

123 Using simultaneous collection of all $\mathrm{Pb}$ masses and their isotopic ratios, the precision of the 
$124{ }^{208} \mathrm{~Pb} /{ }^{206} \mathrm{~Pb}$ can be better than $0.05 \%$. Typical multicollector methods include the collection of

125 the less abundant ${ }^{204} \mathrm{~Pb}$ allowing more detailed examination of the isotope ratios involving ${ }^{204} \mathrm{~Pb}$

126 and the ability to identify sources that may not be distinct on ${ }^{206} \mathrm{~Pb}$-normalized plots. For the best

127 performance of the instrument and to provide the closest compositional match between samples

128 and standards, $\mathrm{Pb}$ is separated from other elements in the sample digests. Purification and

129 isolation of $\mathrm{Pb}$ was achieved through the use of anion exchange chromatographic columns

130 (AG1x8 100-200 mesh resin). To minimize analytical blanks, blood samples were processed

131 through small volume $(100 \mu \mathrm{L})$ teflon columns. Samples with higher Pb concentrations were

132 processed through larger teflon columns that contain $1 \mathrm{~mL}$ of resin to accommodate the larger

133 quantity of $\mathrm{Pb}$ present in the sample aliquots, and to prevent contamination of the columns used

134 for the low $\mathrm{Pb}$ samples. For both column sizes, samples were loaded in $\mathrm{HBr}$ onto pre-cleaned and 135 conditioned anion exchange resin. Major cations were washed in $\mathrm{HBr}$ and $\mathrm{Pb}$ was collected in $136 \mathrm{HCl}$. We followed a Pb separation technique similar to Strelow 1978, Manton 1988, Kamber 137 and Gladu 2009, and Kraus and Nelson 1958. ${ }^{2-5}$ Purified $\mathrm{Pb}$ fractions were dried and treated with 138 concentrated $\mathrm{HNO}_{3}$ and $\mathrm{H}_{2} \mathrm{O}_{2}$ to oxidize any organic residue from the resin, a requirement for a 139 stable signal in the mass spectrometer. Finally, dried, purified $\mathrm{Pb}$ separates were dissolved in $2 \%$ $140 \mathrm{HNO}_{3}$ for isotopic analysis. The mass of each sample loaded onto the columns varied with 141 sample $\mathrm{Pb}$ concentration to target a total $\mathrm{Pb}$ mass of at least $1 \mu \mathrm{g}$ for mass spectrometric analysis. 142 Blood was sample limited and all of the available blood sample was used. Procedural blanks for 143 samples dissolved and processed on the lower volume columns contained $20 \mathrm{pg} \mathrm{Pb}$ which 144 represents less than a $1 \%$ contribution to the smallest blood samples $(2 \mathrm{ng})$ and is considered 145 negligible. Procedural blanks for the higher $\mathrm{Pb}$ concentration samples processed via microwave 146 digestion and larger ion exchange columns averaged $106 \mathrm{pg} \mathrm{Pb}(\mathrm{n}=6)$ representing less than 
$147 \quad 0.05 \%$ of the total average sample separation of greater than $1 \mu \mathrm{g}$. Column yields were greater 148 than $85 \%$.

$149 \mathrm{~Pb}$ isotopic composition measurements were made using a $\mathrm{Nu}$ Plasma High Resolution

150 MC-ICP-MS. The 14 Faraday and 3 ion counting detectors allow for the simultaneous

151 determination of multiple $\mathrm{Pb}$ isotope ratios. Samples containing greater than $5 \mathrm{ng} \mathrm{Pb}$ were

152 analyzed using Faraday detectors and smaller sample sizes (low BLL samples) were analyzed

153 using the ion counting detectors.

154 To increase sensitivity, samples were aspirated through a $\mathrm{Nu}$ Instruments Desolvating

155 Nebuliser and analyzed as a dry plasma. Uptake rates were $50 \mu \mathrm{L} / \mathrm{min}$ and sample solution 156 concentrations were approximately $10 \mathrm{ng} / \mathrm{mL}$ measured at masses ${ }^{202} \mathrm{Hg},{ }^{204} \mathrm{~Pb},{ }^{206} \mathrm{~Pb},{ }^{207} \mathrm{~Pb}$, and

$157{ }^{208} \mathrm{~Pb} .{ }^{202} \mathrm{Hg}$ was monitored in each analysis but not readily detected in this analytical set up 158 averaging less than $1 \mathrm{mV}$ of signal. This would result in a contribution of ${ }^{204} \mathrm{Hg}$ to the ${ }^{204} \mathrm{~Pb}$ 159 signal of less than $0.02 \mathrm{mV}$ and was considered negligible on the $200 \mathrm{mV}{ }^{204} \mathrm{~Pb}$ signal.

160 Samples were corrected for instrumental mass fractionation using a sample-standard bracketing

161 technique with SRM-981 as the bracketing standard and assuming exponential mass

162 fractionation. Sample-standard bracketing is a robust analytical method widely accepted for $\mathrm{Pb}$

163 isotope analyses as used by Ewing et al., $2010^{6}$ and Oulhote et al., 2011, ${ }^{7}$ for example, and

164 described by Elburg et al., 2005. ${ }^{8}$ Data were corrected to the TIMS triple-spike SRM-981 values

165 of Galer and Abouchami, 1998. ${ }^{9}$ External reproducibility was monitored through the analysis of

166 the United States Geological Survey basaltic rock standard BCR-2. This standard was selected to

167 monitor the entire analytical process from dissolution through chemistry and mass spectrometric

168 analysis and was processed in parallel with all sample types. Although the major element

169 composition of a basalt is not a direct match to all of the samples in this study, it is similar in 
170 elemental composition and degree of crystallinity to the glassy burner ash and fired clay tablets

171 which are the samples in this study that are most difficult to dissolve. It is a good monitor of

172 possible $\mathrm{Pb}$ loss to fluorides or $\mathrm{Pb}$ contamination during digestion. The wide range of major and

173 trace elements in BCR-2 make it a robust monitor of the chemical separation process used with

174 the most complex sample types in this study. A well characterized, high precision $\mathrm{Pb}$-isotope

175 blood standard is not available. Though having standards with compositions that closely match

176 each sample compositions is ideal, $\mathrm{Pb}$ from all samples and standards have been purified using

177 ion exchange chemistry to minimize potential matrix effects making them similar in composition

178 at the time of analysis. The values $(\mathrm{n}=14)$ during the time of this study are ${ }^{208} \mathrm{~Pb} / 206 \mathrm{~Pb}=2.0584 \pm$

1790.0014 (2 s.d.), ${ }^{207} \mathrm{~Pb} /{ }^{206} \mathrm{~Pb}=0.8302 \pm 0.0035$ (2 s.d.), ${ }^{204} \mathrm{~Pb} / 206 \mathrm{~Pb}=0.0053 \pm 0.0001$ (2 s.d.),

180 consistent with published standard values. ${ }^{10}$

181 Low BLL samples ( $<5 \mathrm{ng} \mathrm{Pb}$ in total sample) were analyzed by peak hopping using 3

182 mass cycles and measuring using 2 ion counters simultaneously (Table S3). Although peak

183 hopping introduces more error, use of the highly sensitive ion counters is necessary to get a

184 stable signal significantly greater than the background noise. Samples were aspirated through an

185 Aridus II desolvation system at an uptake rate of $50-100 \mu \mathrm{L} / \mathrm{min}$ and sample concentration of 0.1

186 to $0.5 \mathrm{ppb}$. As with the previous analytical method, samples were corrected for instrumental

187 mass bias by sample-standard bracketing to SRM-981. External reproducibility is determined by

188 repeated analysis of the USGS rock standard BCR-2 $(n=8)$. Long term average values are

$189{ }^{208} \mathrm{~Pb} / 206 \mathrm{~Pb}=2.0609 \pm 0.0140$ (2 s.d), ${ }^{207} \mathrm{~Pb} / 206 \mathrm{~Pb}=0.8343 \pm 0.0075$ (2 s.d), and ${ }^{204} \mathrm{~Pb} /{ }^{206} \mathrm{~Pb}=$

$190 \quad 0.0054 \pm 0.0003(2 \mathrm{s.d})$, consistent with the standard values..$^{10}$

191

192 References 
193 1. Centers for Disease Control and Prevention, Laboratory Procedure Manual. 2001.

194 2. Strelow, F. W., Distribution coefficients and anion exchange behavior of some elements

195 in hydrobromic-nitric acid mixtures. Analytical Chemistry 1978, 50 (9), 1359-1361.

196 3. Manton, W., Separation of $\mathrm{Pb}$ from young zircons by single-bead ion exchange.

197 Chemical Geology: Isotope Geoscience section 1988, 73 (2), 147-152.

198 4. Kamber, B. S.; Gladu, A. H., Comparison of Pb Purification by Anion-Exchange Resin

199 Methods and Assessment of Long-Term Reproducibility of $\mathrm{Th} / \mathrm{U} / \mathrm{Pb}$ Ratio Measurements by

200 Quadrupole ICP-MS. Geostandards and Geoanalytical Research 2009, 33 (2), 169-181.

201 5. Kraus, K.; Nelson, F., Symposium on Ion Exchange and Chromatography in Analytical

202 Chemistry. ASTM Special Technical Publication 1958, (195), 27.

2036 6wing, S. A.; Christensen, J. N.; Brown, S. T.; Vancuren, R. A.; Cliff, S. S.; Depaolo, D.

$204 \mathrm{~J}$., $\mathrm{Pb}$ Isotopes as an Indicator of the Asian Contribution to Particulate Air Pollution in Urban

205 California. Environmental Science \& Technology 2010, 44 (23), 8911-8916.

$2067 . \quad$ Oulhote, Y.; Le Bot, B.; Poupon, J.; Lucas, J. P.; Mandin, C.; Etchevers, A.; Zmirou-

207 Navier, D.; Glorennec, P., Identification of sources of lead exposure in French children by lead

208 isotope analysis: a cross-sectional study. Environ Health 2011, 10, 75.

209 8. Elburg, M.; Vroon, P.; van der Wagt, B.; Tchalikian, A., $\mathrm{Sr}$ and $\mathrm{Pb}$ isotopic composition

210 of five USGS glasses (BHVO-2G, BIR-1G, BCR-2G, TB-1G, NKT-1G). Chemical Geology

211 2005, $223(4), 196-207$.

212 9. Galer, S. J. G.; Abouchami, W., Practical application of lead triple spiking for correction 213 of instrumental mass discrimination. Mineral. Mag. A 1998, 62, 491--492.

214 10. Weis, D.; Kieffer, B.; Maerschalk, C.; Barling, J.; de Jong, J.; Williams, G. A.; Hanano, 215 D.; Pretorius, W.; Mattielli, N.; Scoates, J. S.; Goolaerts, A.; Friedman, R. M.; Mahoney, J. B., 216 High-precision isotopic characterization of USGS reference materials by TIMS and MC-ICP217 MS. Geochemistry, Geophysics, Geosystems 2006, 7 (8).

218 11. Forsyth, J. E.; Saiful Islam, M.; Parvez, S. M.; Raqib, R.; Sajjadur Rahman, M.; Marie

219 Muehe, E.; Fendorf, S.; Luby, S. P., Prevalence of elevated blood lead levels among pregnant 220 women and sources of lead exposure in rural Bangladesh: A case control study. Environmental

221 Research 2018, 166, 1-9.

222 12. Millot, R.; Allègre, C.-J.; Gaillardet, J.; Roy, S., Lead isotopic systematics of major river 223 sediments: a new estimate of the $\mathrm{Pb}$ isotopic composition of the Upper Continental Crust.

224 Chemical Geology 2004, 203 (1), 75-90.

225 13. Sen, I. S.; Bizimis, M.; Tripathi, S. N.; Paul, D., Lead isotopic fingerprinting of aerosols 226 to characterize the sources of atmospheric lead in an industrial city of India. Atmospheric

227 Environment 2016, 129, 27-33. 
231 Table S1. Sample collection and analyses conducted in the parent ${ }^{11}$ versus current study.

\begin{tabular}{lcc}
\hline & $\begin{array}{c}\text { Prior case- } \\
\text { control study }\end{array}$ & $\begin{array}{c}\text { Current } \\
\text { study }\end{array}$ \\
\hline Blood sample collection and $[\mathrm{Pb}]$ measurement & $\mathrm{X}$ & \\
Can sample collection and $[\mathrm{Pb}]$ measurement & $\mathrm{X}$ & $\mathrm{X}$ \\
Food from cans sample collection and $[\mathrm{Pb}]$ measurement & & $\mathrm{X}$ \\
Turmeric and pigments sample collection and $[\mathrm{Pb}]$ measurement & & $\mathrm{X}$ \\
Clay and ash sampling and $[\mathrm{Pb}]$ measurement & & $\mathrm{X}$ \\
All Pb isotope measurements & & \\
\hline
\end{tabular}

234 Table S2. Dissolution reagents for each source sample type.

\begin{tabular}{ll}
\hline Sample type & Reagents \\
\hline Can solder & Concentrated $\mathrm{HCl}\left(\right.$ TraceMetal $^{\circledR}$ grade $)$ \\
Burner ash/clay & Concentrated $\mathrm{HF}$ and $\mathrm{HNO}_{3}\left(\mathrm{Optima}^{\circledR}\right.$ grade $)$ \\
Turmeric & Concentrated $\mathrm{HNO}_{3}\left(\mathrm{TraceMetal}^{\circledR}\right.$ grade $)$ \\
Blood & Concentrated $\mathrm{H}_{2} \mathrm{O}_{2}$ and $\mathrm{HNO}_{3}\left(\mathrm{Optima}^{\circledR}\right.$ grade $)$ \\
Food & Concentrated $\mathrm{HNO}_{3}\left(\mathrm{TraceMetal}^{\circledR}\right.$ grade $)$ \\
\hline
\end{tabular}

236 Table S3. Dynamic routine for the collection of $\mathrm{Pb}$ on ion counters IC0 and IC1. The Nu Plasma

237 HR has fixed collectors and in the mass range of $\mathrm{Pb}$ they are 1 atomic mass unit (AMU) apart.

238 The ion counters are positioned with a fixed Faraday detector in between them. Multiple

239 analytical cycles are required to collect both odd and even masses. The magnet mass is changed

240 to cycle the masses onto the appropriate collectors.

\begin{tabular}{llcl}
\hline & IC0 & L3 & IC1 \\
\hline Cycle 1 & 208 & - & 206 \\
Cycle 2 & 207 & - & \\
Cycle 3 & 206 & - & 204 \\
\hline
\end{tabular}

242 Table S4. Summary of sample type, quantity, and lead $(\mathrm{Pb})$ concentrations $(\mu \mathrm{g} / \mathrm{g})$ in food from

$243 \mathrm{~Pb}$-soldered and non- $\mathrm{Pb}$-soldered containers from 40 residents in the study region. 


\begin{tabular}{ccccc}
\hline & Sample type & $\begin{array}{c}\text { Number of } \\
\text { samples }\end{array}$ & $\begin{array}{c}\text { Number of samples }>2.5 \\
\mu \mathrm{g} / \mathrm{g} \mathrm{Pb}\end{array}$ & {$[\mathrm{Pb}]$ if $>2.5 \mu \mathrm{g} / \mathrm{g} \mathrm{Pb}$} \\
\hline \multirow{3}{*}{ Pb-soldered can } & Lentil & 1 & 0 & $15.3,14.1$ \\
& Rice & 17 & 2 & 20.3 \\
\hline \multirow{2}{*}{ Non Pb-soldered } & Turmeric powder & 1 & 1 & 0 \\
containers & Lentil & 1 & 0 \\
& Rice & 18 & 0 \\
\hline
\end{tabular}

${ }^{\mathrm{a}}$ uncooked, boiled, puffed, powdered, or flattened

246 Table S5. Summary of sample type, quantity, and $\mathrm{Pb}$ concentrations $(\mu \mathrm{g} / \mathrm{g})$ in clay and ash from 247 study participants and neighboring markets.

\begin{tabular}{lcc}
\hline Sample type & $\begin{array}{c}\text { Number of } \\
\text { samples }\end{array}$ & $\begin{array}{c}\text { Mean } \pm \text { s.d. } \\
(\mu \mathrm{g} / \mathrm{g})\end{array}$ \\
\hline Clay (tirhi) & 3 & $43.9 \pm 1.6$ \\
Clay (Pot, Toy) & 5 & $41.2 \pm 2.4$ \\
Ash (from burner) & 20 & $33.6 \pm 6.0$ \\
Total & 28 & $35.8 \pm 6.6$ \\
\hline
\end{tabular}

249 Table S6. Summary of turmeric samples from four major retail markets in two districts (all in $250 \mu \mathrm{g} / \mathrm{g})$.

\begin{tabular}{cccc}
\hline Market & $\begin{array}{c}\text { Number of } \\
\text { Samples }\end{array}$ & $\begin{array}{c}\text { Mean } \pm \text { s.d. } \\
(\mu \mathrm{g} / \mathrm{g})\end{array}$ & $\begin{array}{c}\text { Number of samples } \\
>2.5 \mu \mathrm{g} / \mathrm{g} \mathrm{Pb}\end{array}$ \\
\hline 1 & 8 & $1.4 \pm 0.8$ & 0 \\
2 & 7 & $45.9 \pm 108.8$ & 4 \\
3 & 6 & $6.4 \pm 7.9$ & 3 \\
4 & 7 & $1.7 \pm 2.7$ & 1 \\
\hline Total & 28 & $13.7 \pm 54.8$ & 8
\end{tabular}


252 Table $\mathbf{S 7}$. Measured $\mathrm{Pb}$ isotope and concentration data for all samples.

\begin{tabular}{|c|c|c|c|c|c|c|c|c|}
\hline Sample ID & Sample type & $\begin{array}{l}{[\mathrm{Pb}]} \\
(\mu \mathrm{g} / \mathrm{dL} \text { or } \\
\mu \mathrm{g} / \mathrm{g})^{\mathrm{a}}\end{array}$ & $\begin{array}{l}{ }^{208} \mathrm{~Pb} / \\
{ }^{206} \mathrm{~Pb} \\
\text { mean }\end{array}$ & $\begin{array}{l}{ }^{208} \mathrm{~Pb} /{ }^{206} \mathrm{~Pb} \\
\text { s.d. }\end{array}$ & $\begin{array}{l}{ }^{207} \mathrm{~Pb} / \\
{ }^{206} \mathrm{~Pb} \text { mean }\end{array}$ & $\begin{array}{l}{ }^{207} \mathrm{~Pb} /{ }^{206} \mathrm{~Pb} \\
\text { s.d. }\end{array}$ & $\begin{array}{l}{ }^{204} \mathrm{~Pb} / \\
{ }^{206} \mathrm{~Pb} \text { mean }\end{array}$ & $\begin{array}{l}{ }^{204} \mathrm{~Pb}^{/ 206} \mathrm{~Pb} \\
\text { s.d. }\end{array}$ \\
\hline B66901 & Blood & 1.8 & 2.0979 & 0.0166 & 0.8637 & 0.0031 & 0.0556 & 0.0001 \\
\hline B24302 & Blood & 1.1 & 2.1203 & 0.0067 & 0.8670 & 0.0005 & 0.0557 & 0.0004 \\
\hline B27201 & Blood & 9.6 & 2.1171 & 0.0006 & 0.8704 & 0.0001 & 0.0557 & 0.0000 \\
\hline B27503 & Blood & 9.0 & 2.1173 & 0.0012 & 0.8692 & 0.0003 & 0.0554 & 0.0001 \\
\hline B27808 & Blood & 1.8 & 2.1345 & 0.0037 & 0.8788 & 0.0010 & 0.0555 & 0.0001 \\
\hline B29503 & Blood & 6.8 & 2.1155 & 0.0010 & 0.8678 & 0.0007 & 0.0555 & 0.0000 \\
\hline B30302 & Blood & 15.3 & 2.1203 & 0.0012 & 0.8711 & 0.0003 & 0.0557 & 0.0000 \\
\hline B30705 & Blood & 29.1 & 2.1207 & 0.0012 & 0.8662 & 0.0002 & 0.0560 & 0.0000 \\
\hline B30806 & Blood & 20.0 & 2.1192 & 0.0005 & 0.8716 & 0.0005 & 0.0558 & 0.0000 \\
\hline B31002 & Blood & 9.3 & 2.1193 & 0.0012 & 0.8719 & 0.0003 & 0.0557 & 0.0001 \\
\hline B31403 & Blood & 19.4 & 2.1190 & 0.0002 & 0.8715 & 0.0000 & 0.0558 & 0.0000 \\
\hline B31501 & Blood & 25.6 & 2.1235 & 0.0010 & 0.8738 & 0.0004 & 0.0559 & 0.0000 \\
\hline B31801 & Blood & 8.4 & 2.1201 & 0.0009 & 0.8721 & 0.0002 & 0.0558 & 0.0001 \\
\hline B32503 & Blood & 25.0 & 2.1200 & 0.0037 & 0.8661 & 0.0021 & 0.0557 & 0.0003 \\
\hline B32801 & Blood & 1.9 & 2.1286 & 0.0037 & 0.8689 & 0.0010 & 0.0556 & 0.0001 \\
\hline B33804 & Blood & 6.7 & 2.1175 & 0.0002 & 0.8697 & 0.0001 & 0.0557 & 0.0000 \\
\hline B34401 & Blood & 7.5 & 2.1164 & 0.0000 & 0.8702 & 0.0000 & 0.0558 & 0.0000 \\
\hline B36202 & Blood & 6.6 & 2.1173 & 0.0000 & 0.8696 & 0.0003 & 0.0556 & 0.0000 \\
\hline B37001 & Blood & 12.9 & 2.1186 & 0.0012 & 0.8706 & 0.0003 & 0.0556 & 0.0001 \\
\hline B38301 & Blood & 7.9 & 2.1166 & 0.0002 & 0.8712 & 0.0000 & 0.0558 & 0.0000 \\
\hline B39208 & Blood & 13.6 & 2.1220 & 0.0001 & 0.8741 & 0.0002 & 0.0560 & 0.0001 \\
\hline B39301 & Blood & 6.6 & 2.1178 & 0.0004 & 0.8694 & 0.0001 & 0.0556 & 0.0000 \\
\hline B40304 & Blood & 6.9 & 2.1200 & 0.0003 & 0.8733 & 0.0001 & 0.0560 & 0.0001 \\
\hline B41001 & Blood & 12.2 & 2.1384 & 0.0007 & 0.8903 & 0.0009 & 0.0566 & 0.0006 \\
\hline B41401 & Blood & 6.8 & 2.1190 & 0.0006 & 0.8706 & 0.0002 & 0.0557 & 0.0000 \\
\hline B41802 & Blood & 6.7 & 2.1163 & 0.0035 & 0.8691 & 0.0032 & 0.0557 & 0.0002 \\
\hline B42003 & Blood & 7.9 & 2.1066 & 0.0004 & 0.8567 & 0.0007 & 0.0553 & 0.0001 \\
\hline B44405 & Blood & 10.2 & 2.1153 & 0.0028 & 0.8667 & 0.0016 & 0.0554 & 0.0001 \\
\hline B44501 & Blood & 7.2 & 2.1143 & 0.0039 & 0.8632 & 0.0023 & 0.0555 & 0.0002 \\
\hline B44602 & Blood & 7.1 & 2.1168 & 0.0004 & 0.8693 & 0.0001 & 0.0556 & 0.0001 \\
\hline B44704 & Blood & 7.4 & 2.1173 & 0.0005 & 0.8698 & 0.0001 & 0.0557 & 0.0000 \\
\hline B44901 & Blood & 7.0 & 2.1208 & 0.0012 & 0.8715 & 0.0002 & 0.0558 & 0.0000 \\
\hline B52101 & Blood & 10.0 & 2.1155 & 0.0012 & 0.8681 & 0.0003 & 0.0562 & 0.0001 \\
\hline B54001 & Blood & 6.8 & 2.1221 & 0.0002 & 0.8737 & 0.0003 & 0.0559 & 0.0000 \\
\hline B54902 & Blood & 1.8 & 2.1051 & 0.0040 & 0.8706 & 0.0004 & 0.0560 & 0.0000 \\
\hline B55702 & Blood & 6.9 & 2.1164 & 0.0012 & 0.8695 & 0.0004 & 0.0557 & 0.0000 \\
\hline B58003 & Blood & 1.8 & 2.1196 & 0.0012 & 0.8639 & 0.0002 & 0.0559 & 0.0000 \\
\hline B58902 & Blood & 7.2 & 2.1195 & 0.0019 & 0.8715 & 0.0029 & 0.0559 & 0.0001 \\
\hline B59904 & Blood & 1.9 & 2.1261 & 0.0106 & 0.8735 & 0.0022 & 0.0555 & 0.0002 \\
\hline B60701 & Blood & 6.6 & 2.1179 & 0.0021 & 0.8696 & 0.0027 & 0.0557 & 0.0002 \\
\hline B60906 & Blood & 1.9 & 2.1150 & 0.0029 & 0.8692 & 0.0013 & 0.0558 & 0.0001 \\
\hline B63004 & Blood & 9.1 & 2.1205 & 0.0040 & 0.8700 & 0.0037 & 0.0558 & 0.0003 \\
\hline B64602 & Blood & 7.6 & 2.1191 & 0.0013 & 0.8694 & 0.0001 & 0.0557 & 0.0000 \\
\hline B66801 & Blood & 6.7 & 2.1187 & 0.0003 & 0.8724 & 0.0001 & 0.0559 & 0.0000 \\
\hline B67602 & Blood & 9.2 & 2.1178 & 0.0012 & 0.8708 & 0.0003 & 0.0557 & 0.0001 \\
\hline
\end{tabular}




\begin{tabular}{|c|c|c|c|c|c|c|c|c|}
\hline B70003 & Blood & 1.7 & 2.0956 & 0.0040 & 0.8680 & 0.0033 & 0.0555 & 0.0001 \\
\hline CB30603 & Clay & 41.0 & 2.0863 & 0.0050 & 0.8319 & 0.0035 & 0.0528 & 0.0003 \\
\hline CP24302 & Clay & 44.6 & 2.0830 & 0.0006 & 0.8218 & 0.0001 & 0.0506 & 0.0000 \\
\hline CP30603 & Clay & 41.0 & 2.0865 & 0.0023 & 0.8321 & 0.0014 & 0.0528 & 0.0001 \\
\hline CT56002 & Clay & 39.9 & 2.0722 & 0.0006 & 0.8125 & 0.0001 & 0.0499 & 0.0000 \\
\hline SM-Tirhi & Clay & 42.4 & 2.0849 & 0.0006 & 0.8219 & 0.0001 & 0.0506 & 0.0000 \\
\hline Tirhi27808 & Clay & 45.6 & 2.0835 & 0.0003 & 0.8296 & 0.0001 & 0.0526 & 0.0000 \\
\hline Tirhi30302 & Clay & 43.6 & 2.0878 & 0.0035 & 0.8323 & 0.0024 & 0.0528 & 0.0002 \\
\hline RSB30302 & Ash & 35.9 & 2.0912 & 0.0002 & 0.8330 & 0.0056 & 0.0529 & 0.0025 \\
\hline RSB30705 & Ash & 35.9 & 2.0959 & 0.0001 & 0.8384 & 0.0000 & 0.0533 & 0.0000 \\
\hline RSB30705 & Ash & 35.9 & 2.0900 & 0.0003 & 0.8344 & 0.0001 & 0.0530 & 0.0000 \\
\hline RSB31002 & Ash & 29.7 & 2.0844 & 0.0005 & 0.8247 & 0.0058 & 0.0516 & 0.0014 \\
\hline RSB31203 & Ash & 29.4 & 2.0936 & 0.0003 & 0.8366 & 0.0001 & 0.0532 & 0.0000 \\
\hline RSB31403 & Ash & 29.0 & 2.0866 & 0.0006 & 0.8231 & 0.0001 & 0.0507 & 0.0000 \\
\hline RSB31501 & Ash & 27.9 & 2.0860 & 0.0006 & 0.8225 & 0.0001 & 0.0507 & 0.0000 \\
\hline RSB31603 & Ash & 28.6 & 2.0884 & 0.0006 & 0.8273 & 0.0001 & 0.0510 & 0.0000 \\
\hline RSB25404 & Ash & 36.7 & 2.0867 & 0.0006 & 0.8228 & 0.0001 & 0.0507 & 0.0000 \\
\hline 32203Bcan & Solder from can & 214700.8 & 2.1318 & 0.0001 & 0.8857 & 0.0000 & 0.0569 & 0.0000 \\
\hline 58902can & Solder from can & 244850.3 & 2.1328 & 0.0001 & 0.8863 & 0.0000 & 0.0569 & 0.0000 \\
\hline $60602 \mathrm{can}$ & Solder from can & 107011.2 & 2.1285 & 0.0003 & 0.8828 & 0.0001 & 0.0567 & 0.0000 \\
\hline C32202A & Solder from can & 393852.8 & 2.1345 & 0.0021 & 0.8875 & 0.0017 & 0.0570 & 0.0002 \\
\hline C63004 & Solder from can & 278698.6 & 2.1340 & 0.0045 & 0.8879 & 0.0036 & 0.0571 & 0.0004 \\
\hline L35food & Food from can & 14.0 & 2.1310 & 0.0015 & 0.8835 & 0.0003 & 0.0567 & 0.0000 \\
\hline L38food & Food from can & 20.3 & 2.1301 & 0.0009 & 0.8825 & 0.0002 & 0.0565 & 0.0000 \\
\hline L40food & Food from can & 15.3 & 2.1258 & 0.0006 & 0.8786 & 0.0001 & 0.0564 & 0.0000 \\
\hline $\mathrm{T}-13$ & Turmeric & 292.3 & 2.1080 & 0.0174 & 0.8680 & 0.0000 & 0.0556 & 0.0000 \\
\hline $\mathrm{T}-151$ & Turmeric & 1151.9 & 2.1262 & 0.0002 & 0.8786 & 0.0000 & 0.0564 & 0.0000 \\
\hline $\mathrm{T}-235$ & Turmeric & 1002.2 & 2.1167 & 0.0002 & 0.8653 & 0.0000 & 0.0554 & 0.0000 \\
\hline $\mathrm{T}-240$ & Turmeric & 320.5 & 2.1162 & 0.0002 & 0.8649 & 0.0001 & 0.0543 & 0.0014 \\
\hline $\mathrm{T}-244$ & Turmeric & 195.9 & 2.1162 & 0.0006 & 0.8651 & 0.0001 & 0.0543 & 0.0014 \\
\hline T-288 & Turmeric & 62.5 & 2.1160 & 0.0004 & 0.8651 & 0.0001 & 0.0543 & 0.0014 \\
\hline T-306 & Turmeric & 689.7 & 2.1206 & 0.0002 & 0.8680 & 0.0000 & 0.0556 & 0.0000 \\
\hline $\mathrm{T}-34$ & Turmeric & 8.4 & 2.1156 & 0.0002 & 0.8643 & 0.0000 & 0.0553 & 0.0000 \\
\hline $\mathrm{T}-35$ & Turmeric & 59.2 & 2.1165 & 0.0000 & 0.8653 & 0.0000 & 0.0554 & 0.0000 \\
\hline $\mathrm{T} 15$ & Turmeric & 3.4 & 2.1091 & 0.0002 & 0.8562 & 0.0000 & 0.0547 & 0.0000 \\
\hline T248-2017 & Turmeric & 488.4 & 2.1162 & 0.0002 & 0.8648 & 0.0000 & 0.0554 & 0.0000 \\
\hline T67305 & Turmeric & 264.5 & 2.1183 & 0.0028 & 0.8661 & 0.0018 & 0.0554 & 0.0001 \\
\hline $\mathrm{T} 85$ & Turmeric & 18.2 & 2.1158 & 0.0002 & 0.8645 & 0.0000 & 0.0553 & 0.0000 \\
\hline 107-peuri & Yellow pigment & 101300.0 & 2.1180 & 0.0002 & 0.8656 & 0.0000 & 0.0553 & 0.0000 \\
\hline 108-peuri & Yellow pigment & 72040.0 & 2.1279 & 0.0002 & 0.8789 & 0.0000 & 0.0564 & 0.0000 \\
\hline 184-peuri & Yellow pigment & 61870.0 & 2.1090 & 0.0002 & 0.8640 & 0.0000 & 0.0552 & 0.0000 \\
\hline
\end{tabular}


261 Figure S1. Pb-soldered can used to store dried foods.
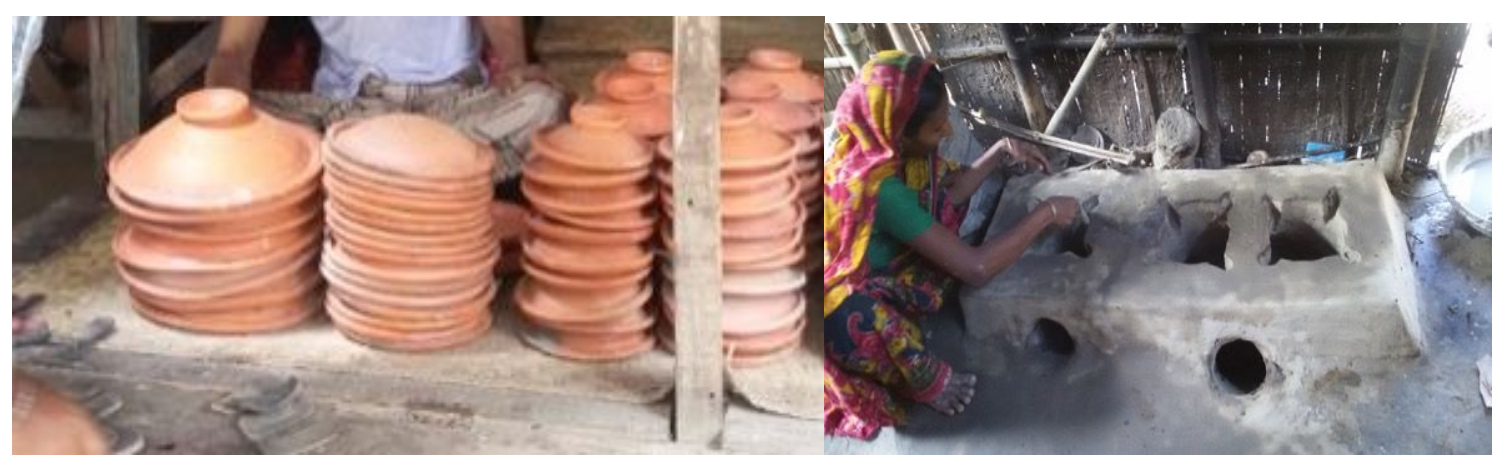

264 Figure S2. (Left) Clay pots in the background and clay tablets (tirhi) in the foreground

265 specifically formulated and sold for pregnant women. (Right) Woman demonstrating where ash 266 from the outdoor stove is collected for consuming during pregnancy. 


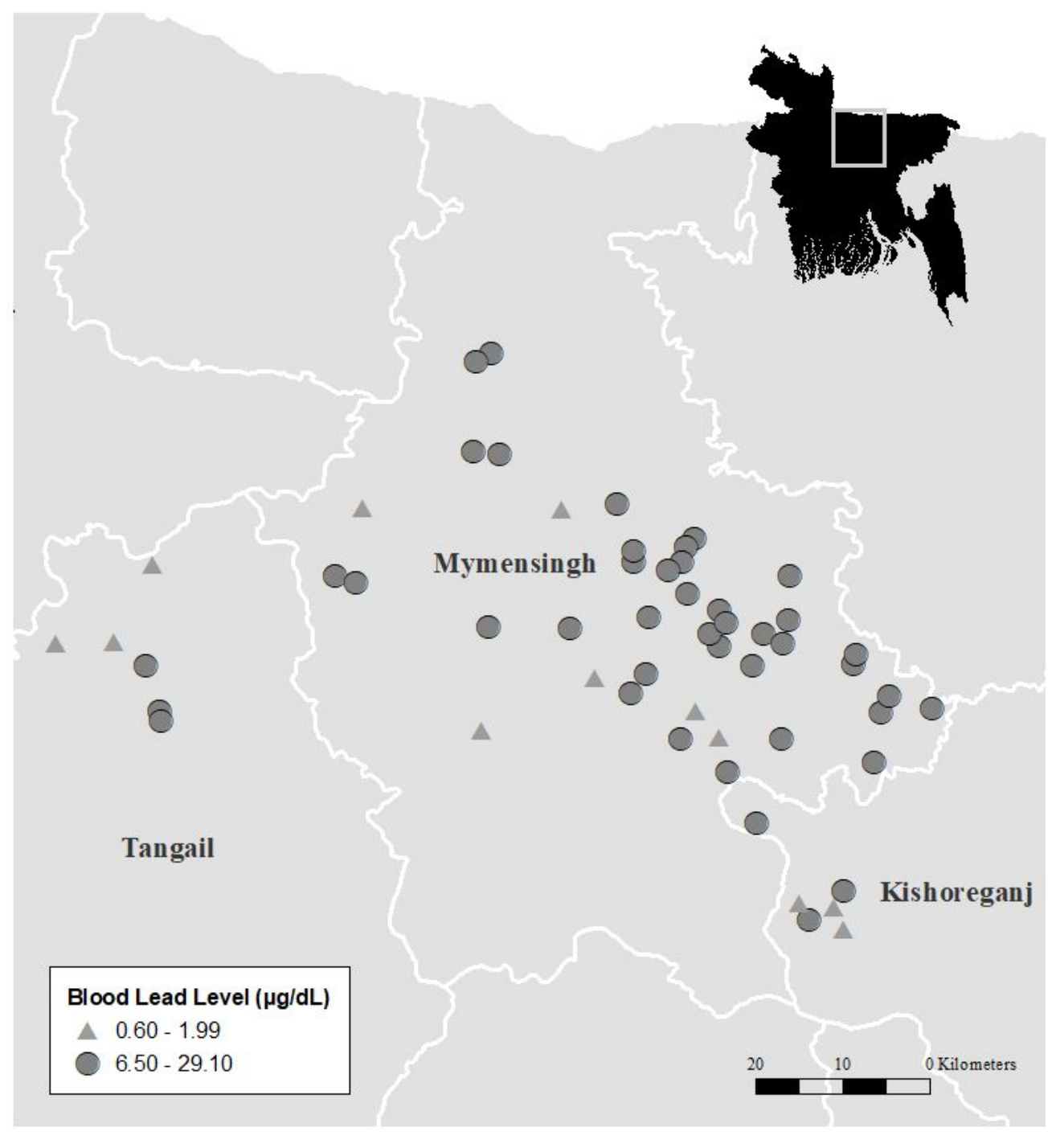

269 Figure S3. Location and blood lead levels (BLLs) of household participants in Tangail,

270 Mymensingh, and Kishoreganj, three rural agrarian districts of Bangladesh. Those with elevated 271 BLLs, $>6.5 \mu \mathrm{g} / \mathrm{dL}$, denoted by larger markers and household participants with low BLLs, $<2$ $272 \mu \mathrm{g} / \mathrm{dL}$, denoted by smaller markers. 


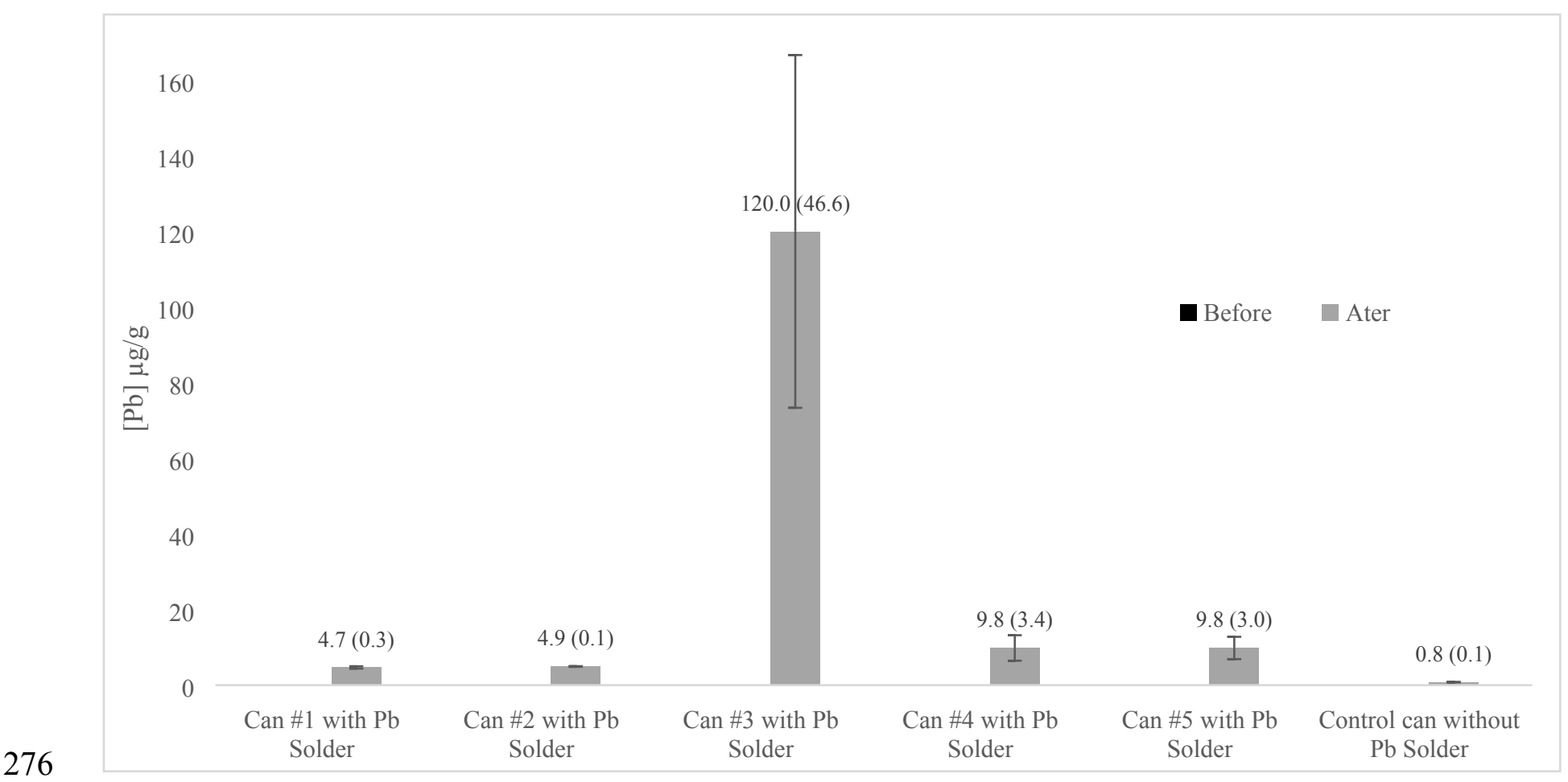

277 Figure S4. Mean lead $(\mathrm{Pb})$ concentrations $(\mu \mathrm{g} / \mathrm{g})$ of puffed rice measured by ICP-MS before and 278 after shaking in Pb-soldered cans (\#1-5) and a control can with no Pb solder. Mean and standard 279 error values from the duplicate experiment noted on the graph. Before shaking, puffed rice $\mathrm{Pb}$ 280 concentrations were $<\operatorname{LOD}(0.001 \mu \mathrm{g} / \mathrm{g})$. 

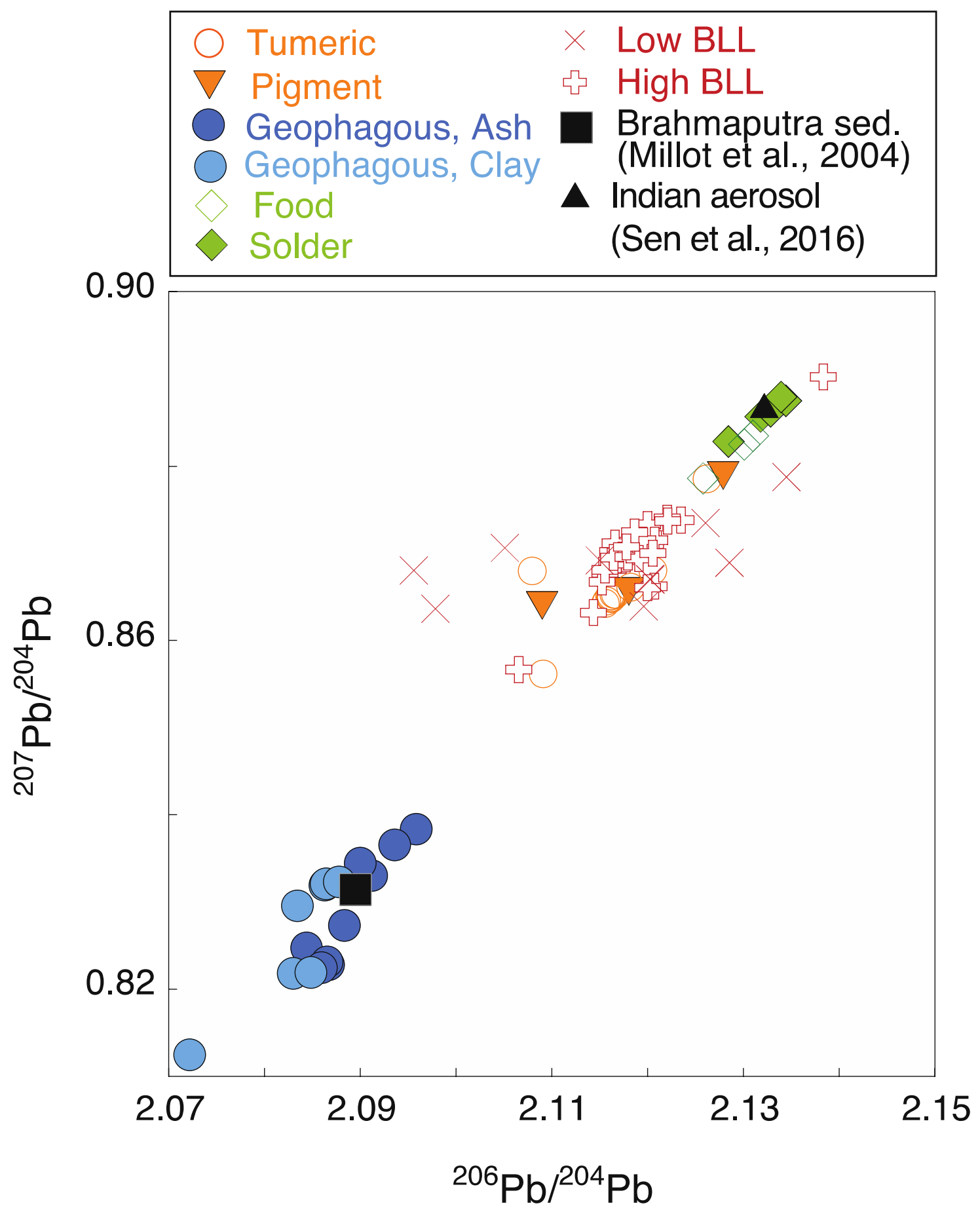

284 Figure S5. Comparison of isotope ratios $\left({ }^{207} \mathrm{~Pb} /{ }^{206} \mathrm{~Pb}\right.$ vs. $\left.{ }^{208} \mathrm{~Pb} / 206 \mathrm{~Pb}\right)$ in women's blood and $\mathrm{Pb}-$ 285 soldered cans, food from $\mathrm{Pb}$-soldered cans, ash, clay, turmeric, and yellow pigment collected 286 from study participants and surrounding markets in Tangail, Mymensingh, and Kishoreganj, 287 Bangladesh, 2015-2017. Representative reference values plotted for sediment from the nearby 
288 region, Brahmaputra headwaters ${ }^{12}$ and for industrial aerosols from nearby Kanpur, northern 289 India. ${ }^{13}$

290 

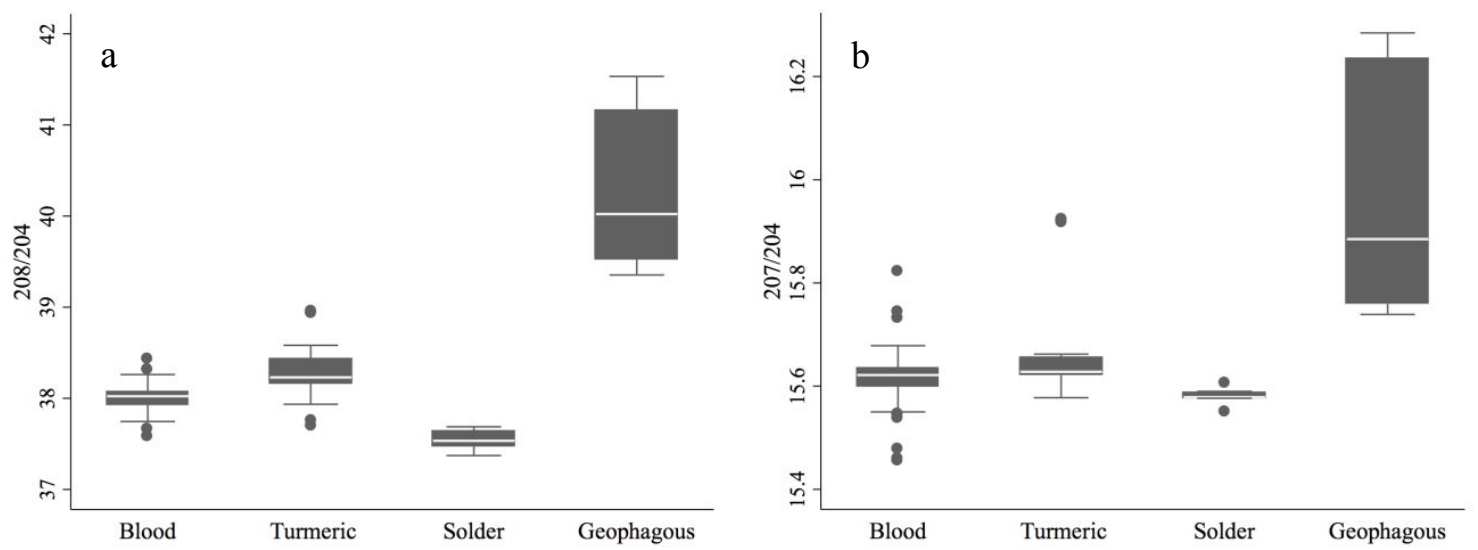

291

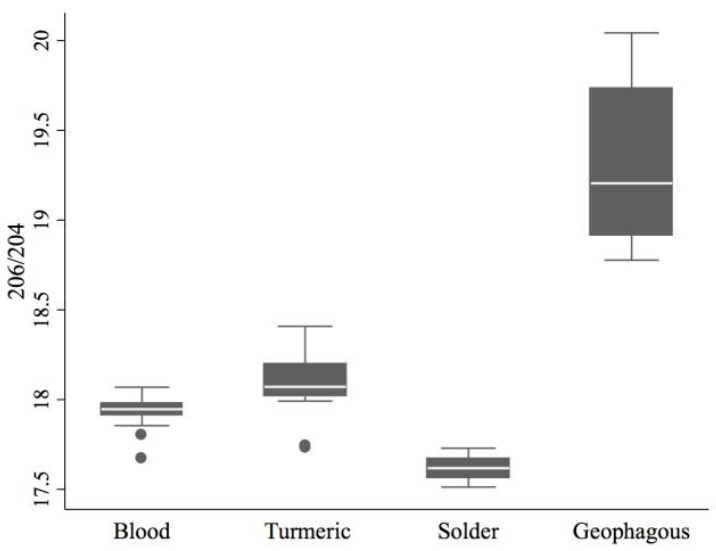

292

Figure S6a-c. Comparison of isotope ratios ${ }^{208} \mathrm{~Pb} /{ }^{204} \mathrm{~Pb},{ }^{207} \mathrm{~Pb} / 204 \mathrm{~Pb}$, and ${ }^{206} \mathrm{~Pb} /{ }^{204} \mathrm{~Pb}$ for blood and $\mathrm{Pb}$ exposures aggregated by source

294 type: turmeric-related materials (turmeric and yellow pigment), solder-related materials ( $\mathrm{Pb}$-soldered cans and food stored within), and

295 geophagous materials (ash and clay) collected from study participants and surrounding markets in Tangail, Mymensingh, and

296 Kishoreganj, Bangladesh, 2015-2017. Figure S6a: ${ }^{208} \mathrm{~Pb} /{ }^{204} \mathrm{~Pb}$ median (IQR) values for blood (38.0234 (37.9481-38.0608)), turmeric

297 (38.2299 (38.1752-38.3612)), solder (37.5341 (37.4822-37.6206)) and ash/clay (40.0221 (39.5288-41.1600)). Figure S6b: ${ }^{207} \mathrm{~Pb} /{ }^{204} \mathrm{~Pb}$

298 median (IQR) values for blood (15.6223 (15.6036-15.6324)), turmeric (15.6278 (15.6222-15.6515)), solder (15.7849 (15.5774- 
299 15.5849)), and ash/clay (15.8849 (15.7615-16.2339)). Figure S6c: ${ }^{206} \mathrm{~Pb} / 204 \mathrm{~Pb}$ median (IQR) values for blood (17.9433 (17.9069-

300 17.9677)), turmeric (18.0711 (18.0284-18.1516)), solder (17.6181 (17.5705-17.6594)), and ash/clay (19.2051 (18.9283-19.7295)).

301

302

303 

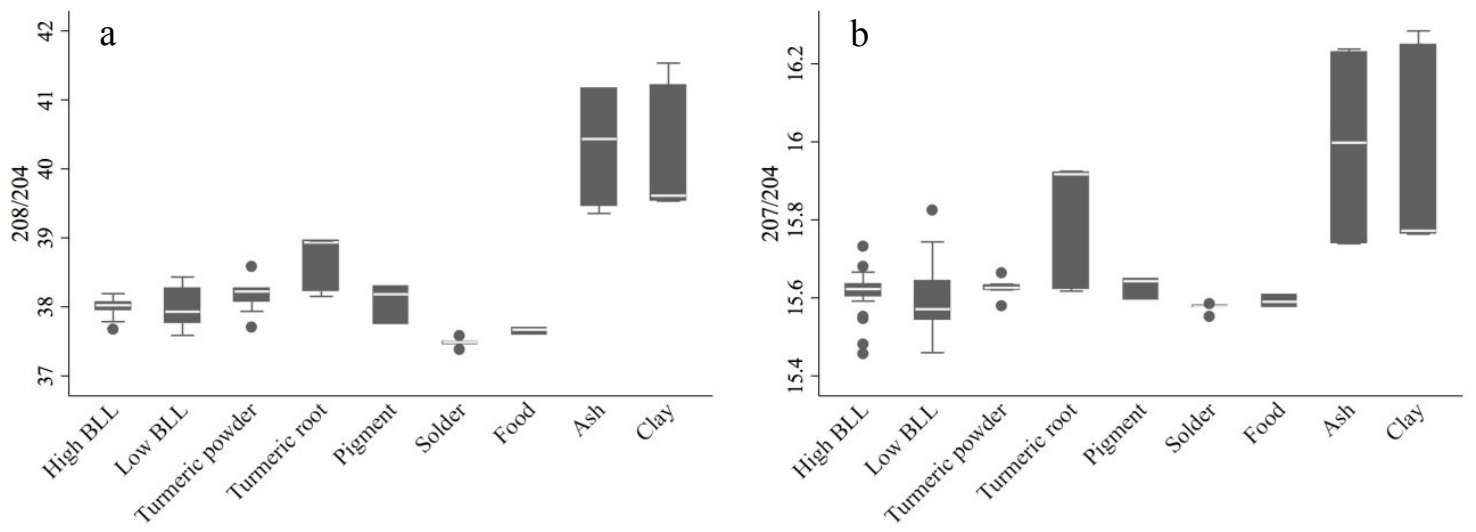

c

304

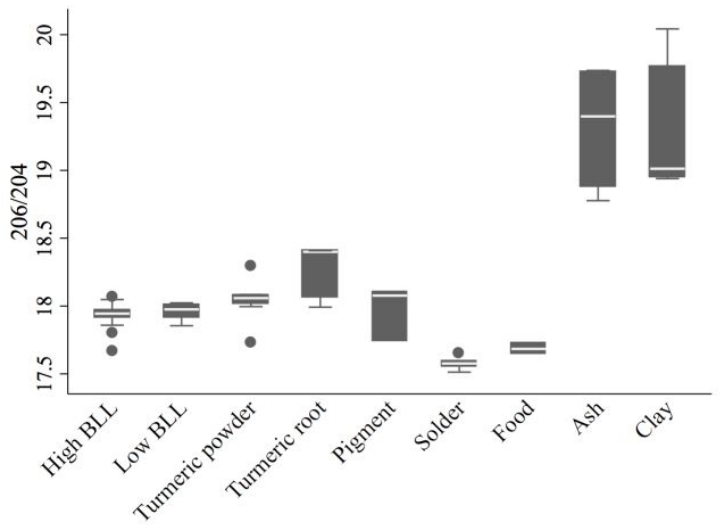

305

306 Figure S7a-c. Comparison of isotope ratios ${ }^{208} \mathrm{~Pb} /{ }^{204} \mathrm{~Pb}$ (Figure $\mathrm{S} 7 \mathrm{a}$ ), ${ }^{207} \mathrm{~Pb} /{ }^{204} \mathrm{~Pb}$ (Figure $\mathrm{S} 7 \mathrm{~b}$ ), and ${ }^{206} \mathrm{~Pb} /{ }^{204} \mathrm{~Pb}$ (Figure S7c) for blood

307 and $\mathrm{Pb}$ exposure sources disaggregated by subtypes collected from study participants and surrounding markets in Tangail,

308 Mymensingh, and Kishoreganj, Bangladesh, 2015-2017.

309

310 


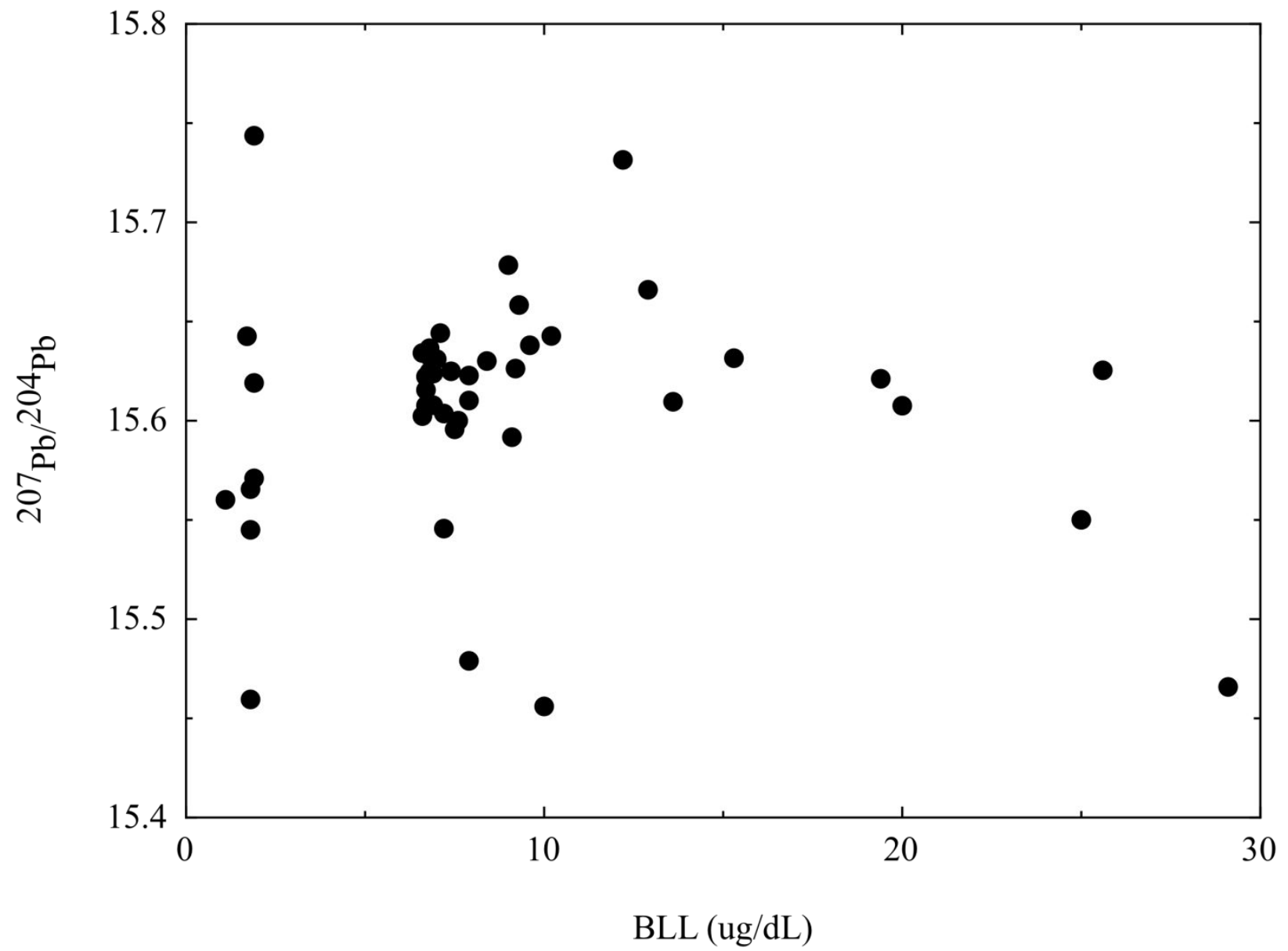

314 Figure S8. Isotope composition $\left({ }^{207} \mathrm{~Pb} / 204 \mathrm{~Pb}\right)$ vs. blood lead level (BLL, $\left.\mu \mathrm{g} / \mathrm{dL}\right)$ for forty-five 315 female participants from rural Tangail, Mymensingh, and Kishoreganj districts, Bangladesh. 316 